\title{
Characterization of lithological zones of the Isanlu sheet 225, North Central Nigeria, using aerogeophysical datasets
}

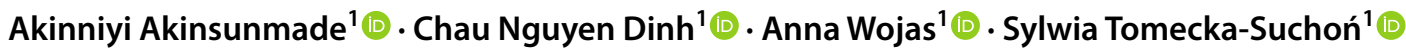

Received: 9 May 2019 / Accepted: 22 February 2020 / Published online: 15 April 2020

(c) The Author(s) 2020

\begin{abstract}
Gridded aeromagnetic and aeroradiometric datasets of Isanlu sheet 225 were processed and interpreted in order to map the geological structures and characteristic lithology, as well as potential mineral ore zones in the area. Recorded aeromagnetic data were reduced to the magnetic equator before filtering operations which enhanced the magnetic anomalies. Analytic signal map was created, and subsequently a model was generated along a selected profile for better interpretation of the subsurface materials. On the aeroradiometric data were performed both enhancement and statistical operations. The lithological zones were identified. They are metasedimentary rocks, migmatites and igneous rocks occupying varying proportions within the entire area. Some potential radioactive or precious metal ore zones were also localized. A major structure interpreted in the study area trends in the SE-NW direction. Other surface structures were also delineated and general orientation was evaluated. This information may serve as a valuable database for further prospective research and mineral exploration in the region.
\end{abstract}

Keywords Aerogeophysical data $\cdot$ Geological structures $\cdot$ Lithology $\cdot$ Isanlu sheet $225 \cdot$ Nigeria

\section{Introduction}

Conventional regional geological mapping and ground geophysical survey on a regional scale may be a Herculean task because of cost of execution, time of completion and inaccessibility at some instances. Therefore, appropriate knowledge and understanding of the general geology of an interesting area may be limited. However, the use of aerogeophysical datasets often enhances the success of the conventional geological mapping, especially for the regions of very large and/or mountainous, as well as allows quick regional reconnaissance (Boadi et al. 2013).

The magnetic method is capable especially of detecting and mapping of igneous extrusive rocks or locating the boundaries of the formations and determining the depth of crystalline basement in sedimentary basins. The measured parameter of the aeromagnetic surveys is total magnetic intensity (TMI) describing influences of stronger/weaker magnetic rocks on the geomagnetic field. The geological

Chau Nguyen Dinh

Nguyen.Chau@fis.agh.edu.pl

1 Faculty of Geology, Geophysics and Environmental Protection, AGH University of Science and Technology, Mickiewicza 30 Ave., 30-059 Kraków, Poland structures (lithology and tectonic) and their parameters (size, shape, depth to the surface, slope) as well as the magnetic properties of the formations can be investigated.

In radiometric surveys, gamma rays from rocks and soils are detected. Using the measured data, one can identify and locate the geological formations as well as occurrence of metal ore deposits. The terrestrial gamma radiation almost comes from the natural isotopes belonging to the decay series, i.e., uranium (U), thorium (Th) and potassium isotope $\left({ }^{40} \mathrm{~K}\right)$.

Nowadays, airborne magnetic and radiometric surveys have been used extensively in the mineral exploration industry predominantly for the delineation of metalliferous deposits (Airo and Loukola-Ruskeeniemi 2004; Adepelumi and Falade 2017). Its application ranges from geological mapping, rock characterization and mineral exploration (Telford et al. 1990). Recently, the accuracy and resolution of these techniques have substantially increased, so that they can be used to provide useful enhanced information on lithology and geological structures. Additionally, advances in data processing and image analysis have improved the resolution of geophysical datasets to discover bodies causing very subtle variations in geophysical responses (Armstrong and Rodeghiero 2006). 
Aero-survey measurements are usually made from lowflying airplanes along closely spaced, parallel flight profiles. The profiles are usually perpendicular to the main geological trending direction. These huge volumes of measurement data are then processed and presented as a digital aero-data map.

Potential gold deposits often occur in the hydrothermal altered zones rich in potassium (Ohioma et al. 2017a,b). The radioactive and heavy metals ores often occur in skarn or suture zones, accompanying with faults characterized by different petrophysical parameters including magnetic susceptibility. Based on the mentioned knowledge, an attempt has been made to interpret airborne radiometric and magnetic datasets to characterize the lithological zones and delineation of the potential metal ore places in the Isanlu sheet 225 North Nigeria.

\section{Geological setting of Nigeria}

The landmass of Nigeria is situated within the Pan-African mobile belt. The belt is sandwiched between two super-crustal terrains, also referred to as African and Congo Craton (Burke and Dewey 1972). The process of the geology formation of the country begins in the Archean and Proterozoic eons in the Precambrian (Obaje 2009).

The geology of Nigeria is dominated by crystalline and sedimentary rocks both occurring approximately in equal proportions (Woakes et al. 1987). Essentially, the regional geology of Nigeria is made up of three major litho-petrological components: the Precambrian Basement Complex, Younger Granites and sedimentary basins. The Precambrian Basement Complex is made up of the migmatite-gneiss complex, the schist belts and the older granite. They are mostly found in the north-central, southwestern and the far eastern flank of Nigeria (Fig. 1). The Precambrian Basement rocks of South West Nigeria found in the Dahomeyan (Benin) Basin, consist of migmatites, banded and granite gneisses, with low-grade metasedimentary and metavolcanic schists, intruded by Pan-African-age granites and charnockites (Oyawoye 1972; Fitches et al. 1985). Within the migmatites and gneissic metasediments, the intrusive pegmatite veins and dykes are often observed (Oluyide et al. 1998). Older granites, granodiorites and syenites, with dolerite dykes also form part of the Precambrian Basement of SW Nigeria. The petrographic characteristic of the older granite is typical leucocratic with gray to greenish tint. The overall texture of the rock as seen in most outcrops is predominantly hypidiomorphic granoblastic, and its dominant mineral components are quartz, plagioclase, microcline and biotite.

The Younger Granites comprise several Jurassic magmatic ring complexes, locating around the Jos Plateau and other parts of North Central Nigeria. The acid nature is the most striking petrographic feature of the Younger Granite. Over $95 \%$ of the rocks can be classified as rhyolites, quartz
Fig. 1 Generalized geological map of Nigeria (Adelana et al. 2008)

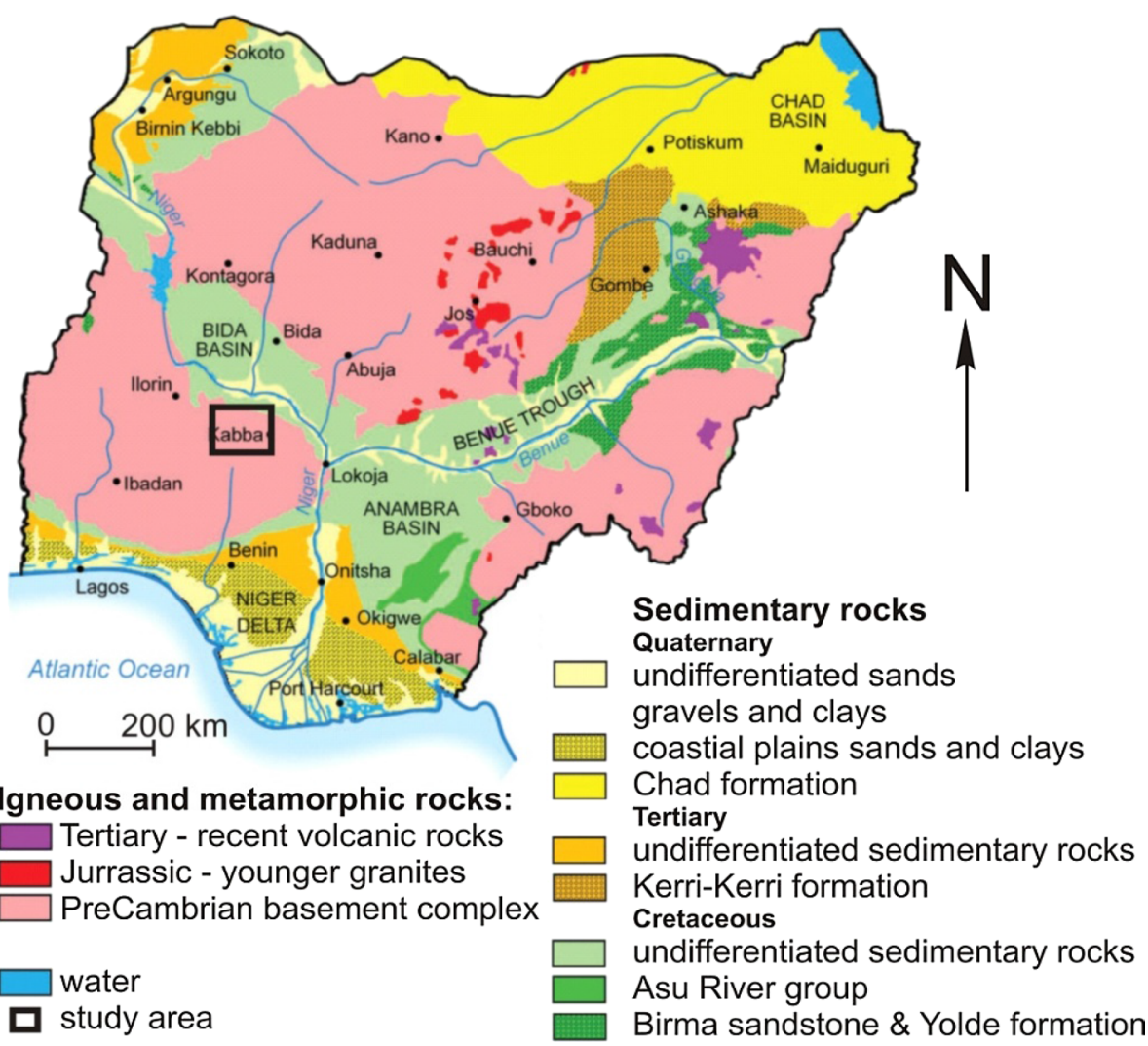


syenites or granites with basic rocks forming the remaining $5 \%$.

The sedimentary sequence includes the Late Jurassic to Early Cretaceous Illo and Gundumi Formations, the Maastrichtian Rima Group, the Late Paleocene Sokoto Group and the Eocene-Miocene Gwandu Formation. Examples of rocks of these formations are shale with intercalations of limestone, siltstone and sandstone. These were deposited during a series of overlapping marine transgressions. The sedimentary basins occupy the central Y-shaped area in the country; they underlie all of southern and are also found in northwest in Sokoto, and in Borno states and the entire Lake Chad in the northeast. The sedimentary basins, containing sediments of Cretaceous to Paleogene, comprise the Niger Delta, the Anambra Basin, the Lower, Middle and Upper Benue Trough, the Chad Basin, the Sokoto Basin, the Mid-Niger (Bida-Nupe) Basin and the Dahomey Basin. The basal formation is made of sandstone. This is overlain by Awgu shale and Nkporo shale. The topmost formation is made of fine to medium sandstone. Solid mineral deposits of economic significance that include gold, iron ore, cassiterite, columbite, wolframite, barites, lead-zinc, pyrochlore, monazite, marble, coal, limestone, clays, etc., occur in the different geologic units of Nigeria (Basement, Younger Granites and sedimentary basins), and indeed each of the 36 federating states and the Federal Capital Territory has a fair share of the solid mineral inventory of the nation (Adelana et al. 2008).

\section{Geology of the study area}

The Isanlu sheet 225 is located in North Central Nigeria between latitude 114,100-169,600 $\mathrm{m}$ and longitude 885,600-941,300 $\mathrm{m}$ in coordinate system WGS84/UTM zone $32 \mathrm{~N}$ (Fig. 2). Major cities in this area include Isanlu, Egbe and Moro. The study area falls within the Precambrian Basement complex with rock classified as the schist belts. The schist belts are predominantly composed of metasedimentary and metavolcanic rocks trending $\mathrm{N}-\mathrm{S}$ which are best developed in the western part of Nigeria (Obaje 2009).

In the studied area, the belts are considered as Upper Proterozoic supracrustal rocks enfolded into the migmatite-gneiss-quartzite complex composing of the coarse- to fine-grained clastic, pelitic schists, phyllites, banded iron formation, carbonate rocks (marbles, dolomitic marbles) and mafic metavolcanics (amphibolite) (Obaje 2009).

The relief of the area is moderate to high with steep to gentle rolling terrain and flat plains. Massifs and round topped hills are common with the highest peak being $2175 \mathrm{~m}$ above sea level (a.s.l) in the southeastern parts of the study area. These parts are predominantly undulating, while in the north the area is relatively low with average height of $750 \mathrm{~m}$ a.s.1.

\section{Methods applied in the study}

The aerogeophysical surveys were performed between 2004 and 2009 by Nigerian Geological Survey Agency (NGSA) using a light aircraft with fixed wings Cessna Titan 404 (C-FYAU). The aircraft had a gamma ray spectrometer mounted on its wings and a magnetometer placed in a cage towed in a housing known as a "bird" behind the aircraft. In the study area, the total measured line amounted to $1,104,174 \mathrm{~km}$ with the used flight parameters summarized in Table 1.

\section{Aeromagnetic data}

The total magnetic intensity (TMI) was acquired using an optically pumped magnetometer Scintrex Cesium SC-2 ${ }^{\mathrm{TM}}$. The magnetic data were sampled at a rate of $0.1 \mathrm{~s}$. The data were made available in the form of grid on a scale of $1: 100,000$. The geomagnetic global field was removed using
Fig. 2 Geological map of the study area (after NGSA 2006)



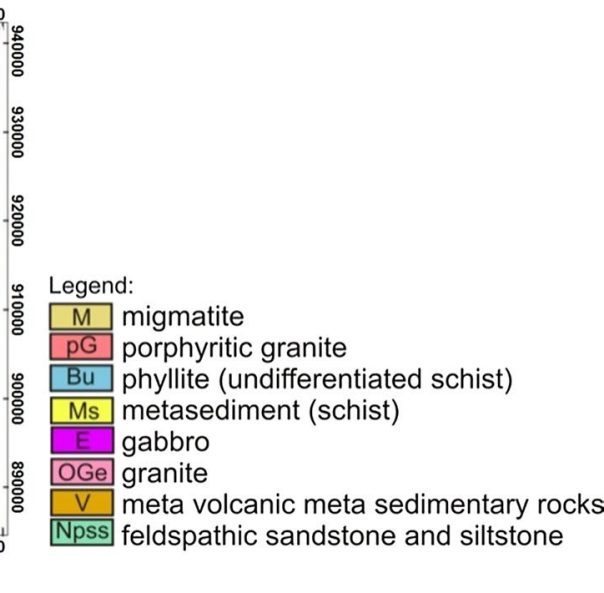


Table 1 Flight parameters used in radiometric and magnetic surveys

\begin{tabular}{ll}
\hline Flight line spacing (profile distance) & $500 \mathrm{~m}$ \\
Terrain clearance (profile height) & $80 \mathrm{~m}$ \\
Flight line direction & $\mathrm{NW}-\mathrm{SE}$ \\
Tie line spacing & $2000 \mathrm{~m}$ \\
Tie line direction & $\mathrm{NE}-\mathrm{SW}$ \\
Flight speed & $250-290 \mathrm{~km} / \mathrm{h}$ \\
\hline
\end{tabular}

the 2010 International Geomagnetic Reference Field (IGRF) (Thébault et al. 2015).

The acquired aero-data were processed using Oasis montaj computer software (version 8.0) and Surfer version 10 developed by Geosoft and Golden software incorporation, respectively.

In the area close to the magnetic equator, the magnetization $(M)$ of the body is consistent with the horizontal component of the Earth's magnetic field $(H)$. Therefore, the TMI anomaly of a single magnetic body surrounded by nonmagnetic medium has the same value and direction as the horizontal component $(\Delta H)$ and is visible on maps as negative magnetic anomaly.

The measured magnetic intensities are presented as a map (Fig. 3a). Reduction to the magnetic equator (RTE) was done using the IGRF model and taking into account the inclination and declination average values of the studied area $I=-9.08^{\circ}, D=-2.17^{\circ}$, respectively (Fig. 3b). The RTE method is based on theoretical moving of the magnetization of the investigated area to the magnetization of the "hypothetic region" located in the equator. It causes the magnetization of rocks and magnetic anomaly positioned directly on the center of magnetic body (Leu 1982).

The data transformation was performed using the MAGMAPTM extension of the Oasis montaj software. The operations in MAGMAP are a range of linear and nonlinear mathematical algorithms which selectively enhance the anomalies related to the groups of the interesting geological source (Milligan and Gunn 1997). They also eliminate the influence of the inclined magnetization occurring in the study region and make the interpretations to be easier. The two-dimensional fast Fourier transform (2D-FFT) is particularly useful in the transformation from the frequency domain to the wave number domain and also for the derivative calculation (Telford et al. 1990). Subsequently, the RTE TMI anomaly was divided into regional and residual anomaly maps.

The regional magnetic anomaly (Fig. 4a) was calculated from the RTE magnetic anomaly using low-pass Gauss and fifth-order Butterworth filters. The residual anomaly map (Fig. 4b) was obtained by the subtraction of the regional magnetic anomaly from the TMI anomaly reduced to the magnetic equator (RTE). In the residual map, some enhancements and transformations were performed to extract the near-surface geology.

Various vertical derivatives of the magnetic field can be computed by multiplying the amplitude spectra of the field by a factor of the form:

$\left[\left(u^{2}+v^{2}\right)^{1 / 2}\right]^{n}$ (a)

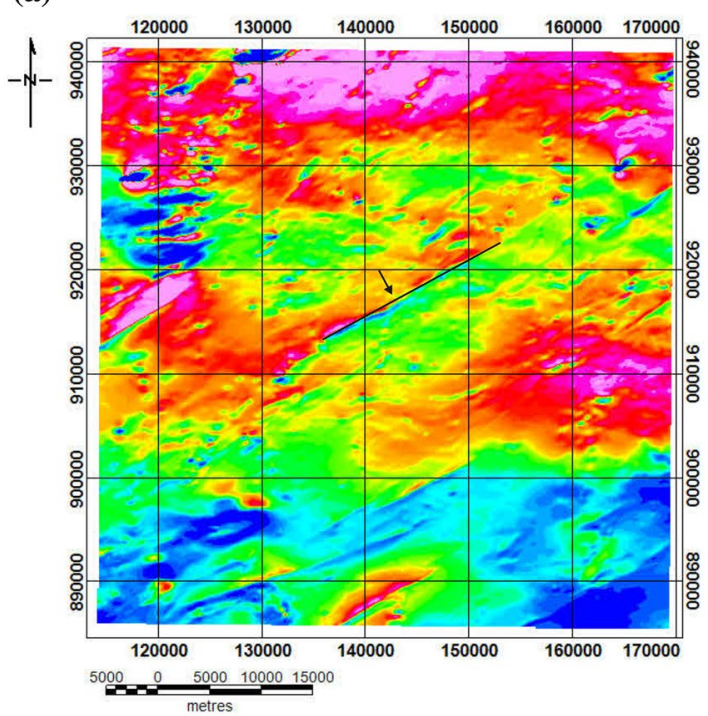

(b)

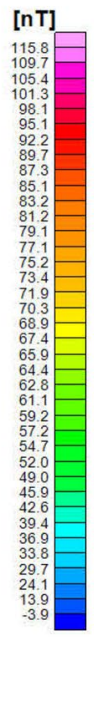

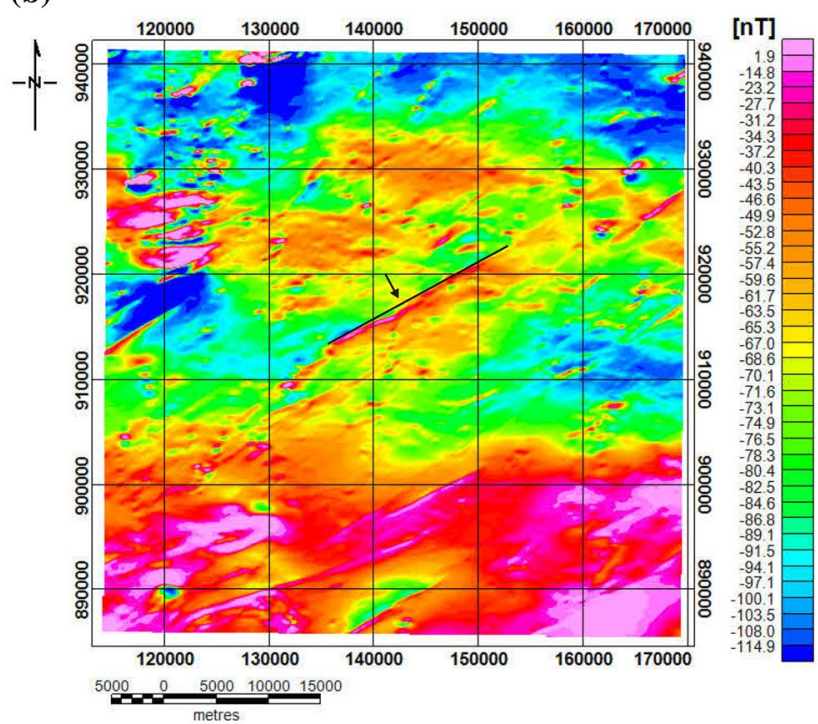

Fig. 3 The total magnetic intensity anomaly map [nT] of the Isanlu sheet 225: a raw magnetic anomaly data, b after reduction to the magnetic equator (RTE), abbreviation: \means a fault 
(a)

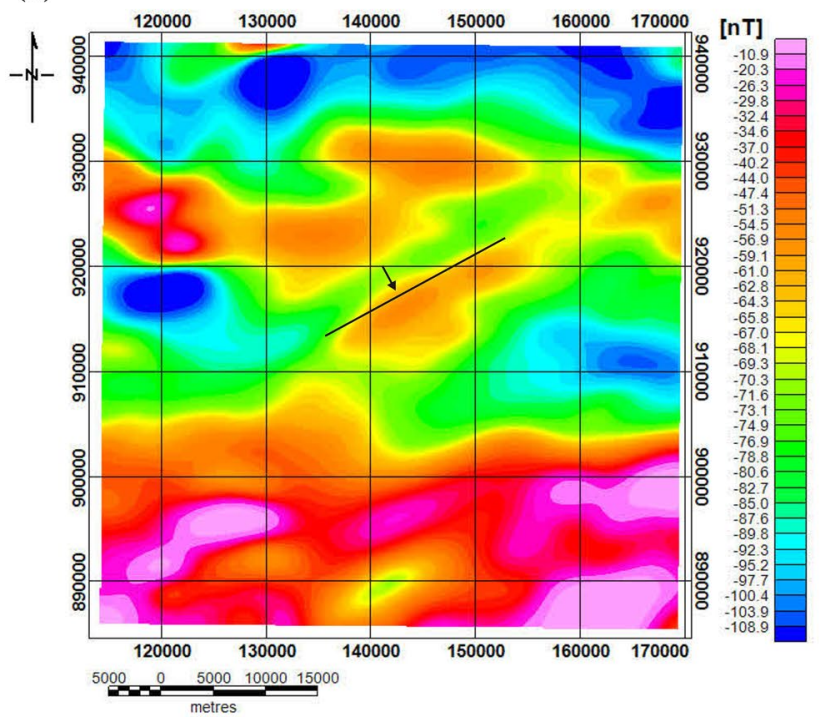

(b)

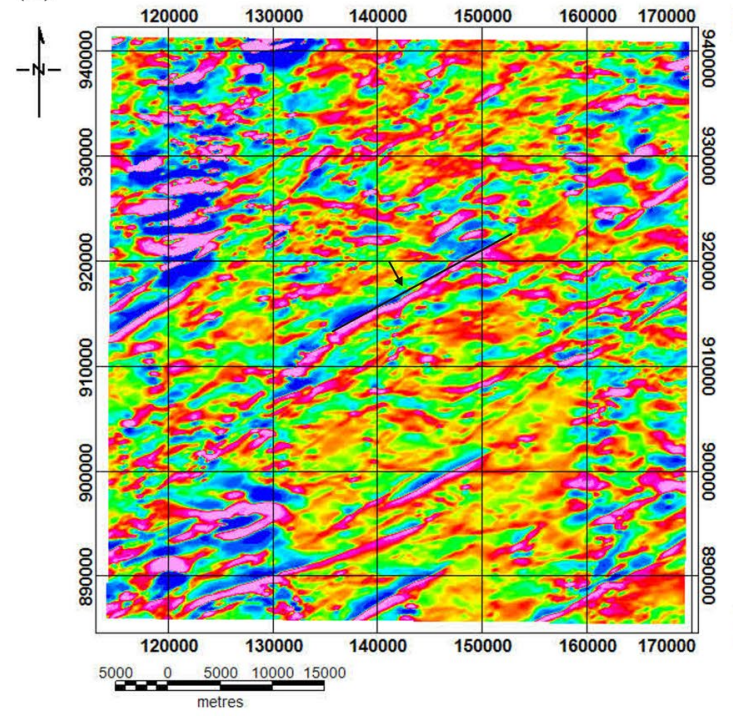



Fig. 4 Magnetic anomaly maps; a the regional anomaly map, b the residual anomaly map, cutoff wavelength 5000 in both cases

where $n$ is the order of the vertical derivative and $(u, v)$ is the wave number corresponding to the $(x, y)$ directions.

The first vertical derivative of the RTE anomaly map for $n=1$ is presented in Fig. $5 \mathrm{a}$, which is showing significant enhancement of the near-surface structures and attenuation of the deeper objects.

The influence of the deeper magnetic responses was also examined using the upward continuation algorithm of the MAGMAP extension. The upward continued $\Delta T$ (the total magnetic field anomaly) at higher level $(z=h)$ is given by (Everett 2013)

$$
\Delta T(x, y,-h)=\frac{h}{2 \pi} \int_{-\infty}^{+\infty} \int_{-\infty}^{+\infty} \frac{\Delta T\left(x^{\prime}, y^{\prime}, 0\right)}{\left(\left(x-x^{\prime}\right)^{2}+\left(y-y^{\prime}\right)^{2}+h^{2}\right)^{\frac{3}{2}}} \mathrm{~d} x^{\prime} \mathrm{d} y^{\prime}
$$

The RTE anomaly map resulted from the upward continuation to $1000 \mathrm{~m}$ (Fig. 5b) clearly reflects only the large structures and is consistent with the regional anomaly map (Fig. 4a).

For the delineation of edges of similar magnetic responses which may coincide with lithological boundary, the (a)

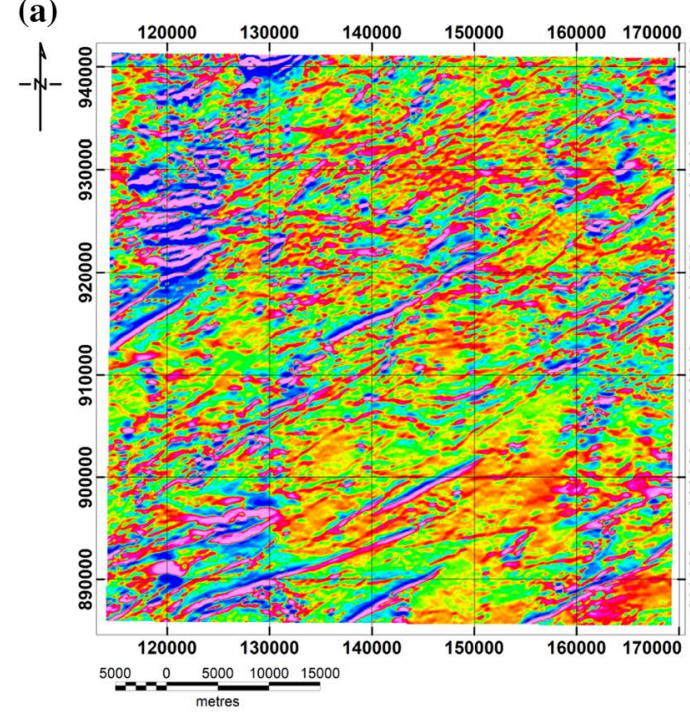

(b)

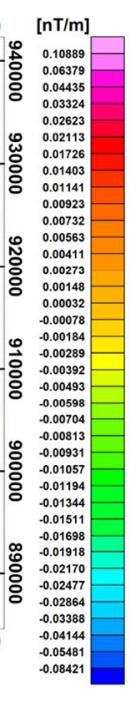

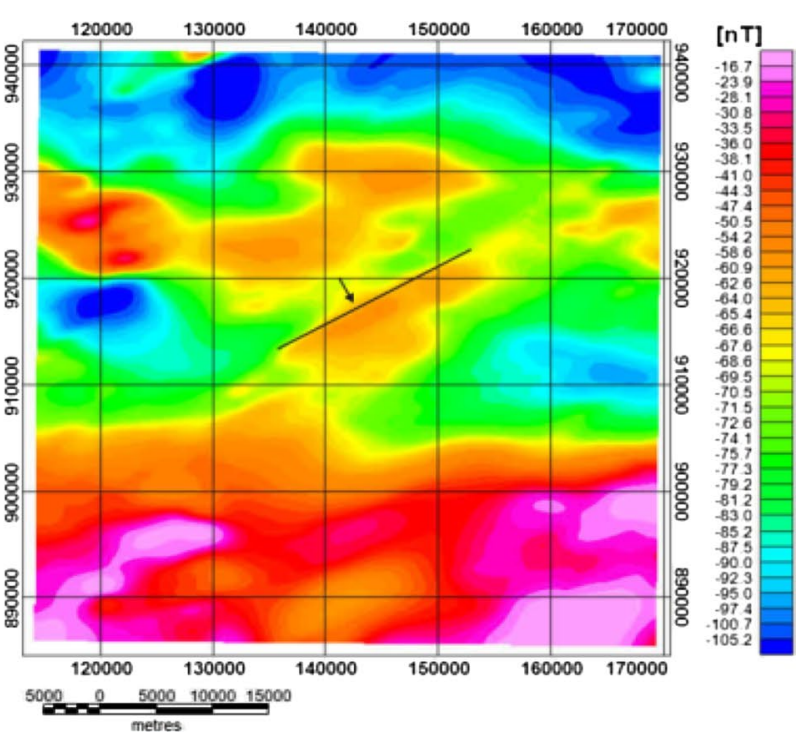

Fig. 5 a First vertical derivative of the RTE anomaly map, b upward continuation to $1000 \mathrm{~m}$ of the RTE anomaly map 
analytical signal filtering was performed. Analytical signal is a process of combining the three directional gradients of the magnetic field to obtain the total gradient and to remove the complexities of derivatives response. The analytical signal $A(x, y)$ at point $(x, y)$ is given by (Dentith and Mudge 2014):

$|\mathbf{A}(x, y)|=\sqrt{\left(\frac{\partial(\Delta T)}{\partial x}\right)^{2}+\left(\frac{\partial(\Delta T)}{\partial y}\right)^{2}+\left(\frac{\partial(\Delta T)}{\partial z}\right)^{2}}$

In addition, a simple magnetic model was generated, constituting a significant part of the quantitative magnetic interpretation (Foss 2011; Petecki and Rosowiecka 2017). The original TMI anomaly data set (with no reduction or transformations of the magnetic data) was used to create a magnetic model along the profile $\mathrm{AB}$ with 78,000 m length.

\section{Aeroradiometric data}

The radiometric data were measured at a rate of $1 \mathrm{~s}$ using a gamma 512 channel spectrometer "Exploranium GR-820" coupled with a solid scintillation detector. The detector is composed of eight crystals with a total volume of 1280 cubic ins. Each crystal has individual pole-zero cancellation, semi-Gaussian shaping and advanced baseline restoration circuitry. In the spectrometer, there is a special channel to record the cosmic rays with high-energy, special analyzer for pulse pileup of signals from single events and reduce the Compton effect. Detector resolution is automatically computed for each crystal during peak analysis and is displayed for operator monitoring when required. The summed down resolution is also output on the data stream. The detailed technical parameters of this tool can be found in the Web site www.gpxsurveys.com.au and the monograph published by Foote and Humphrey (1976). The individual channels show the absolute concentrations of the K (\%), eTh (ppm) and $\mathrm{eU}(\mathrm{ppm})$. Based on the obtained data, the lithological variations were characterized. Moreover, the enhanced aerodatasets were analyzed statistically and presented in various formats such as tables, graphs, rose diagram, pseudo-cross section and maps for interpretations.

\section{Results and discussion}

In this section, the results of the processing of the datasets are presented. Deductions made are based on responses influenced by variations in lithology, alterations, mineralogy and microstructures which form major control of geophysical methods of investigation (Dentith and Mudge 2014). The important considerations to interpretations made in this study are the effects of near-surface covers, regolith and deep responses which may be distorted or attenuated.

\section{Digital topography map}

Digital topography variation of the study area was generated from digital elevation model (DEM) of NASA short radar topography mission (SRTM) data and displayed as image which indicates variation in elevation in meters. Digital elevation data are useful for identifying areas of erosion and sedimentation, where dissected cover is likely as a guide to where bedrock responses are most likely (Dentith and Mudge 2014). The southern half of the area is occupied by high-elevation terrain, ranging from 280 to $481 \mathrm{~m}$, while the northern half has an elevation range of 180 to $260 \mathrm{~m}$ above sea level (Fig. 6). Inferences from elevation variation coincided with some of the responses obtained from the magnetic data (Fig. 3b). The southern zones, particularly SE part, are of very high elevation which may indicate the region of volcanic igneous activities and this may have caused the lifting of the surface.

\section{Aeromagnetic results}

In general, the positive magnetic anomalies with maximum intensity value about $5.0 \mathrm{nT}$ dominate in the south and negative anomalies with the lowest intensities about $-115 \mathrm{nT}$ are observed in the north (Fig. 3b). The difference between the highest and lowest magnetic intensities (amplitude) is equal to $120 \mathrm{nT}$, suggesting that in the study area there are predominantly rocks of weak or even very weak magnetic properties (magnetic susceptibility, magnetization). This type of magnetic property is characteristic of occurrence of acid igneous rock or sedimentary rocks. Sources of the positive magnetic anomalies, occurring near the southern boundary of the studied sheet, may be mafic metavolcanic rocks (e.g., amphibolites) and ultramafic rocks (e.g., peridotite), while the sources of the negative magnetic anomalies characterized of the northern parts suggest the signature of metasedimentary rocks (e.g., phyllites, schist). However, in the northwestern part there is the area of the high enough magnetic intensities, within the negative magnetic intensities regions which may suggest an occurrence of gabbro dykes or faults. The main magnetic anomalies are trending in the SW-NE direction indicating the main geological structures of the area. In the center of the area, there is a magnetic anomaly with $\sim 30 \mathrm{~km}$ of length trending SW-NE direction; this anomaly could be considered as a fault zone (Fig. 3b, with arrow).

Moreover, the map resulted from the upward continuation processing using the Gauss filter (Fig. 4a) indicates the following observations:

1. The positive weak magnetic anomalies on the regional magnetic map are dominant in the southern part of the sheet, and in the NW part several single positive anoma- 
Fig. 6 The digital topography map of the Isanlu sheet 225 . Height difference between the highest and the lowest site amounts to $300 \mathrm{~m}$

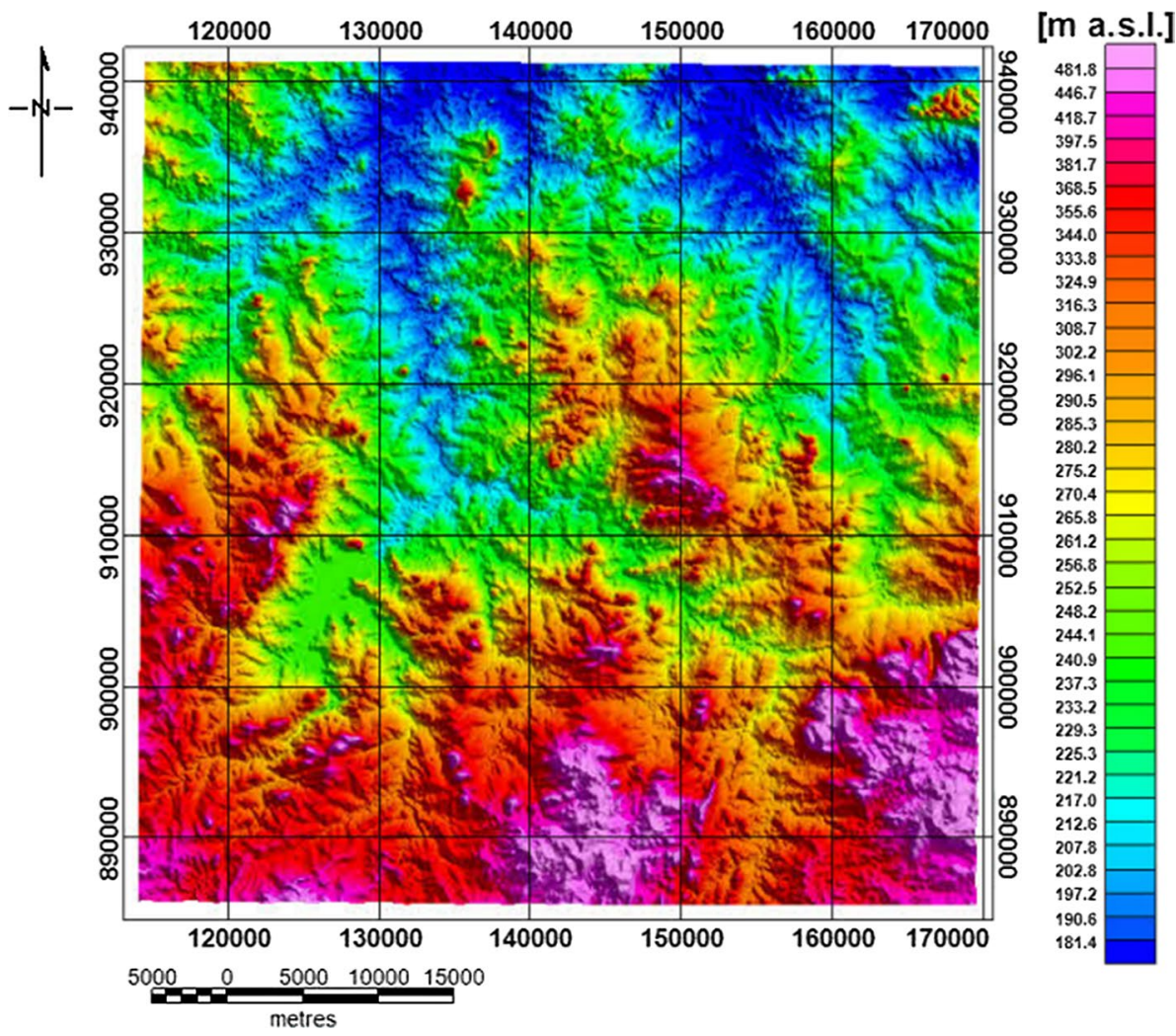

lies are also observed, but their amplitudes are significantly lower in comparison with that in the southern part.

2. The magnetic lineament zone occurring in the central part probably corresponds to a near-surface tectonic unit (fault). The SW-NE trending magnetic lineament almost disappears after performing the upward continuation with the value of $3000 \mathrm{~m}$ (figure not shown in this article).

The first vertical derivative map (Fig. 5a) consists mostly of the local anomalies trending in the SW-NE directions and the near-surface structures which may include lineaments such as fractures and dykes crosscutting the country rocks (Fig. 2). The near-surface structural map of the entire area was generated from the vertical derivative analysis as shown in Fig. 7a. Plot of the orientations of the linear structures on rose diagram (Fig. 7b) shows a general orientation in the ENE-WSW direction.

From the analytical signal (AS) filtering of the magnetic data (Fig. 3b), edges of similar magnetic responses are discernable and are thought to delineate lithological boundaries that produce the responses (Fig. 8a). The edges have enabled the characterization of the entire study area into three major lithology zones (Fig. 8b).

The three major lithological mappable zones are: acid igneous rocks that occupied almost all the four corners of the entire study area (pink), the metasedimentary rocks that formed the dominant lithology extending from the central part to the northern border (yellow), and the migmatite rocks that formed large pockets within the whole area (grey). In Fig. 8b, the igneous rocks include the porphyritic granite, gabbro and granite; the metasediment group is composed of intervolcanic metasediments and metasediment rocks. The rocks in each group are characterized by the similarity in magnetic properties and are not easily distinguished on the analytical signal map. What is more, migmatites are often characterized by a wide range of magnetic properties and occur on the large part of the sheet (Fig. 9).

In order to confirm the assumptions and recognize the magnetic susceptibility $(S)$ of the rocks as well as to view the depth to the top of the basement, a cross section of the profile AB (Fig. 10) was drawn as an example. The profile $\mathrm{AB}$ is selected because it cuts diagonally the sheet with the NW-SE direction and crosses most of the main geological structures of the area. The TMI values measured along this profile were taken to generate the two-dimensional (2D) magnetic model using the GM-SYS Profile Modelling extension of Oasis montaj. Based on the geological data as found in the literature, the magnetic model built on the profile $\mathrm{AB}$ consists of a sedimentary formation and a basement, which relative to AS map is divided into seven blocks with different susceptibility (Fig. 8a). Since there was no magnetic susceptibility $(S)$ data from this 
(a)

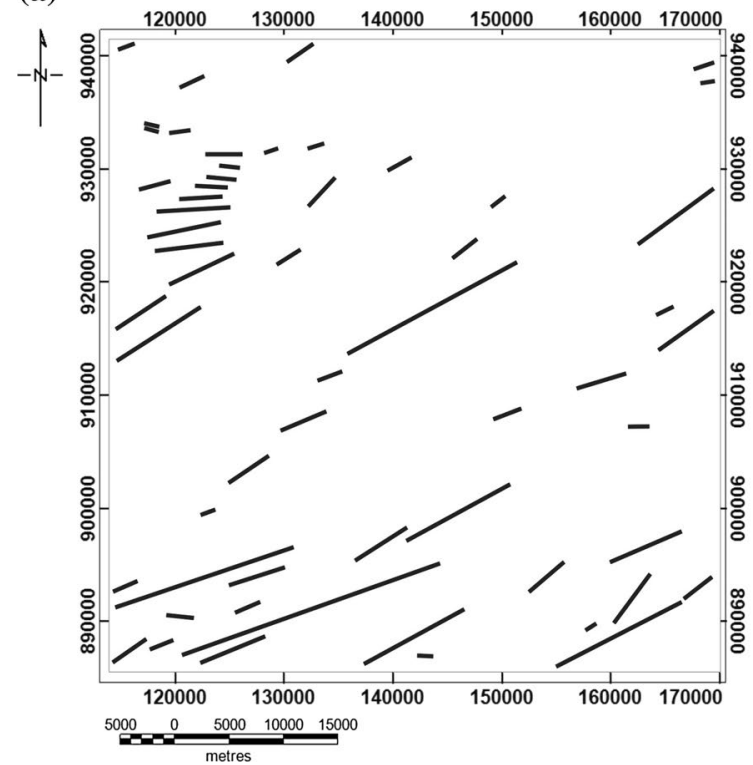

(b)



Fig. 7 a The responses of linear magnetic structures interpreted on the basis of the vertical derivative map, b rose diagram of the detected 57 linear magnetic structures

(a)

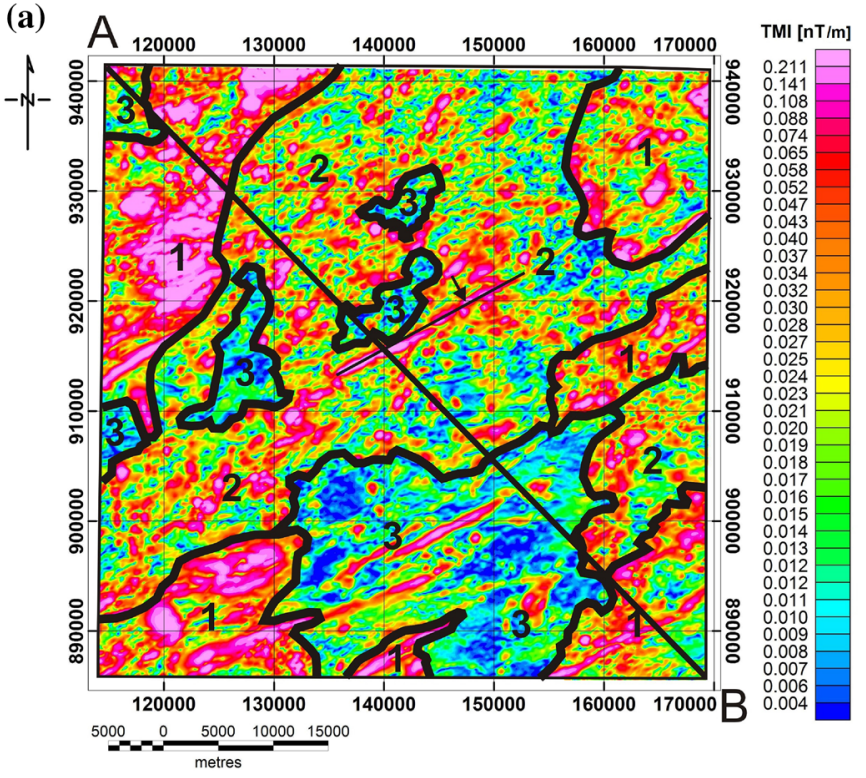

(b)

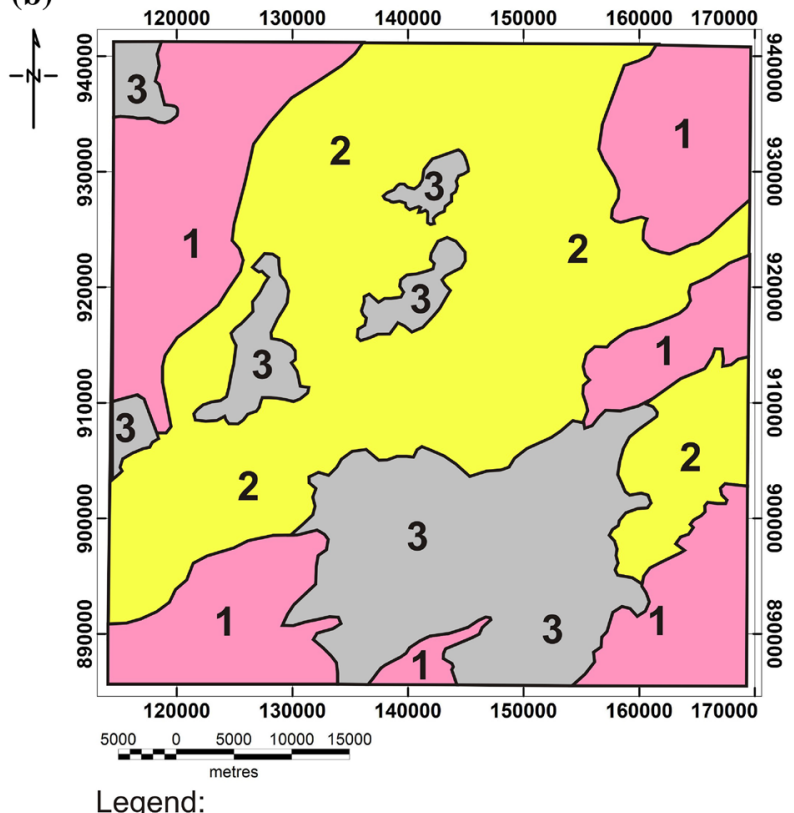

Legend:



Fig. 8 a Analytic signal (AS) map with graphic mapping and profile $\mathrm{AB}, \mathbf{b}$ localization of the lithological zones determined by the means of the analytic signal map and the proposal rocks

region, some $S$ values were assumed for the blocks in the model, taking into account the $S$ values published by Adepelumi and Falade (2017). As a result of modeling, depth, morphology and magnetic susceptibility of the rocks were determined. At the beginning part of the profile, there are suspected gabbro dykes intruded into igneous (probably 
Fig. 9 Magnetic anomaly map (raw magnetic data) with a profile $\mathrm{AB}$
Fig. 10 The magnetic model of basement along the profile $\mathrm{AB}$ (modeling in GM-SYS software)
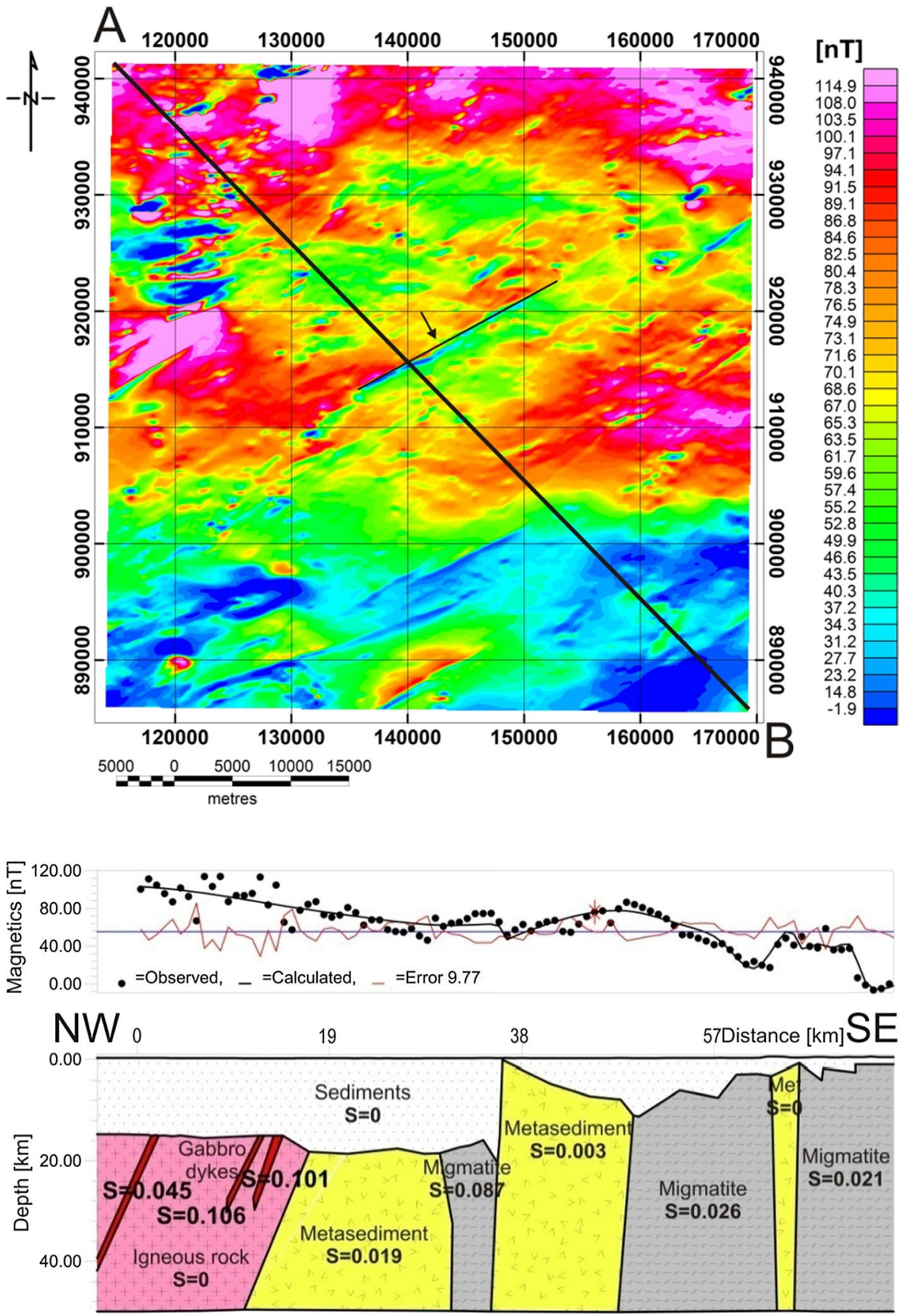

acid) rocks. Magnetic susceptibility values of gabbro dykes and acid igneous rocks amount to about 0.1 and 0.00001 , respectively. It is in agreement with the statement that mafic intrusive igneous rocks (gabbros) are definitely magnetically stronger in comparison with acid igneous rocks (e.g., granite without magnetite grains) (Parasnis 1986). Migmatites in the model have strong responses with high negative magnetic anomalies at the SE end part of the $\mathrm{AB}$ profile (Fig. 10), and their magnetic susceptibility varies from 0.021 to 0.087 . The magnetic susceptibility of metasedimentary rocks ranges from 0.00001 to 0.003 . In the southern part of the studied area, the basement occurs relatively at shallow depth in comparison with other parts. This assertion is corroborated with information extracted from the digital topography map (Fig. 6). In the central and NW parts, the basement could be zones of fracture/ faults which exhibit undulating surface and much thicker sedimentary cover (Fig. 10).

The magnetic model generally is in agreement with the results of qualitative interpretation regarding the basement morphology and the formations crossed along the profile AB (Figs. 8b, 10). 


\section{Aeroradiometric results}

The aeroradiometric data distribution of potassium $(\mathrm{K})$, equivalent uranium (eU) and equivalent thorium (eTh) on the study area are presented in Fig. 11a-c, respectively.

The measured concentrations range from 0.2 to $5 \%$ for potassium, $0.5-12 \mathrm{ppm}$ corresponds to the $6-150 \mathrm{~Bq} / \mathrm{kg}$ for uranium and 3-100 ppm correspond to the range of 12 to near $400 \mathrm{~Bq} / \mathrm{kg}$ for thorium. Generally, the zone of high concentration of all measured natural radionuclides is located in the south of the study area. In this zone, the eTh concentration varies from 30 to $49 \mathrm{ppm}$, eU from 5 to $10 \mathrm{ppm}$ and $\mathrm{K}$ from 2.7 to $4.1 \%$ and suggests areas connected with

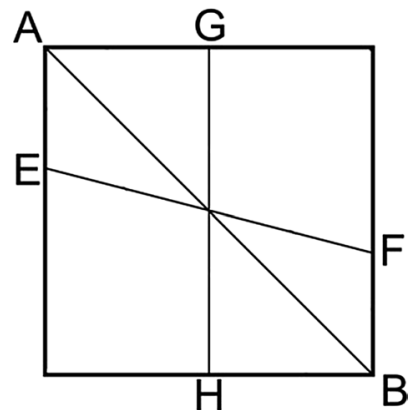

Fig. 12 The scheme of the cross section profiles

(b)

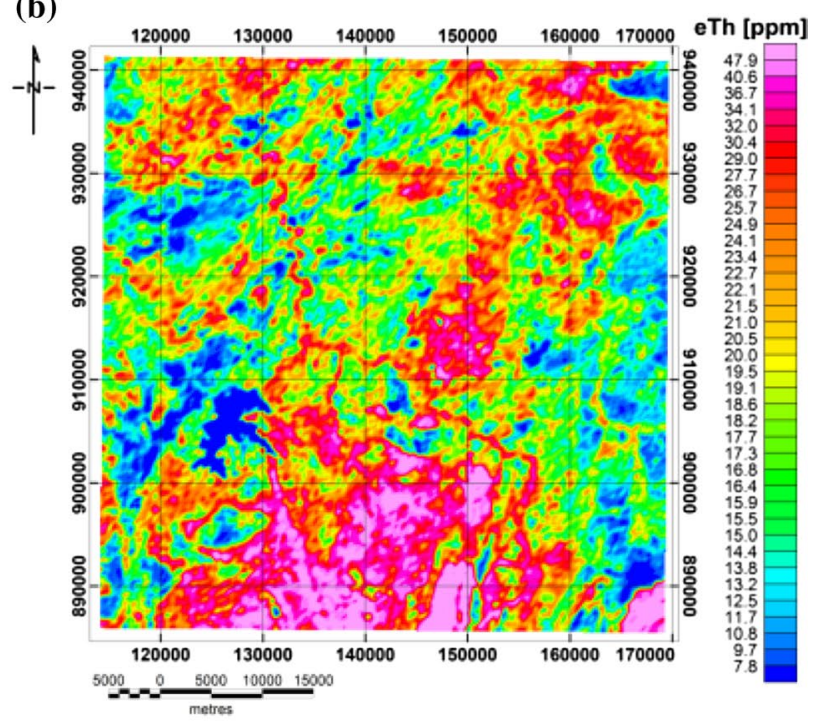

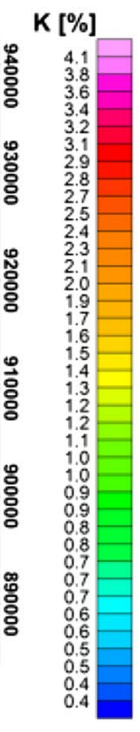

(c) (a)

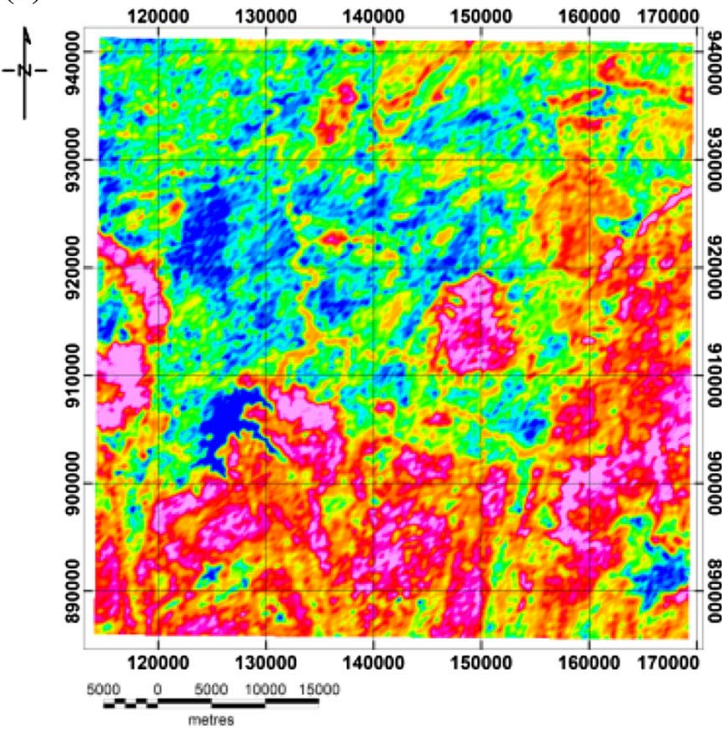

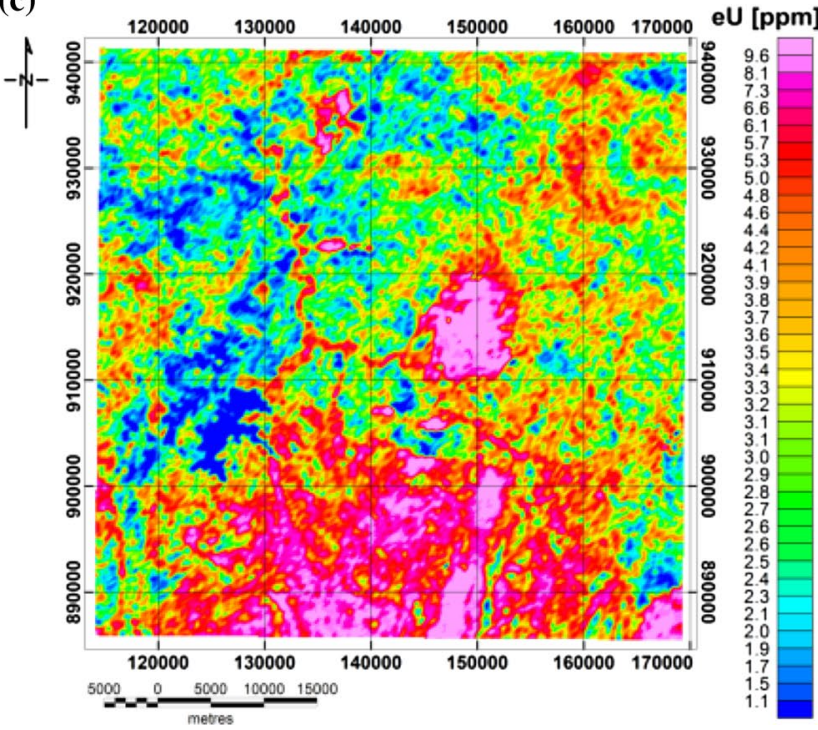

Fig. 11 Radiometric maps: a potassium (K) concentration gridded map in $\%$, b thorium (eTh) concentration gridded map in ppm, $\mathbf{c}$ uranium (eU) concentration gridded map in ppm 

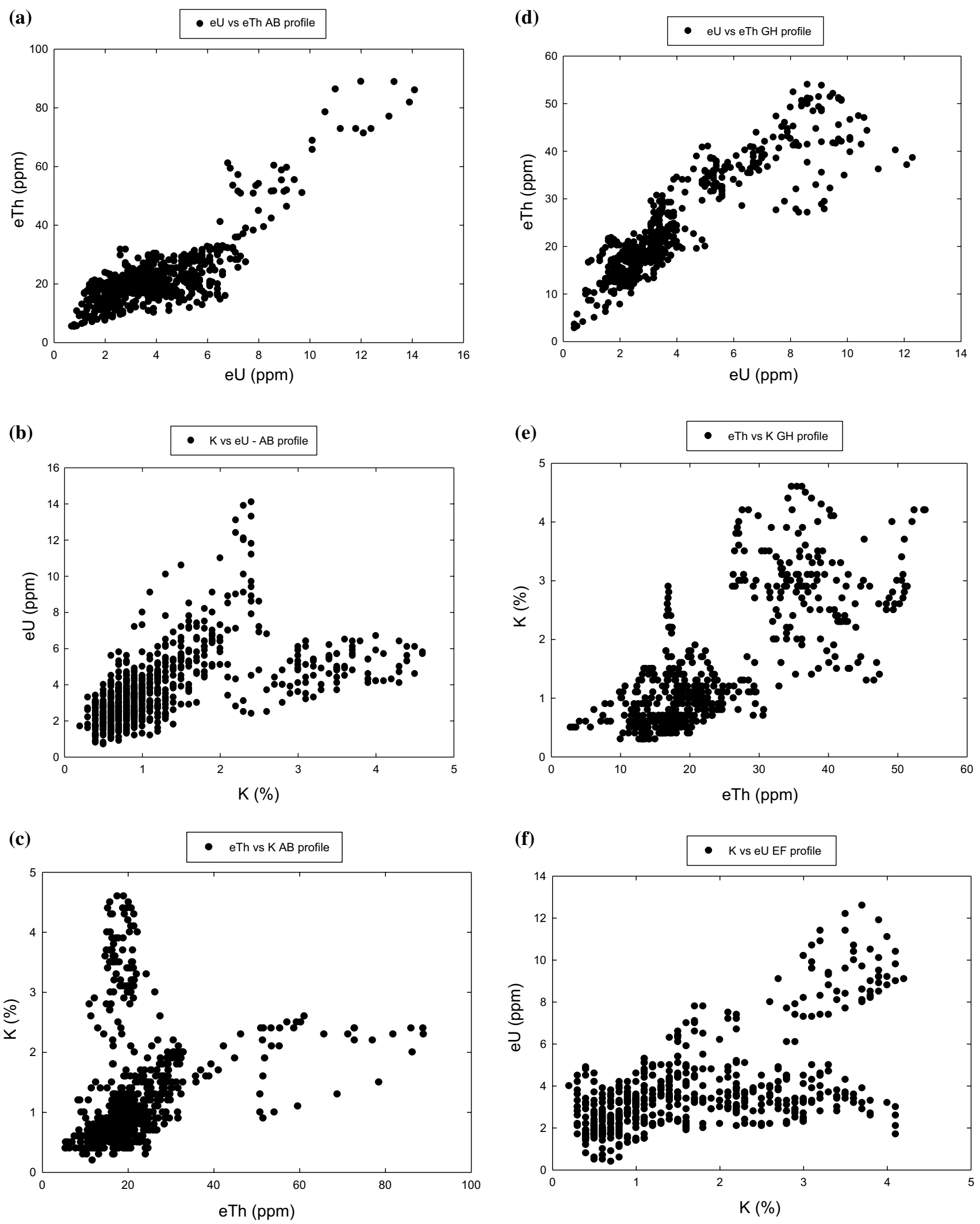

Fig. 13 Plot of relationships of radionuclide elements along some selected profiles; profile AB (a eTh-eU, b eU-K, c K-eTh); profile GH (d eTh-eU, e K-eTh); profile EF (f eU-K) 
Table 2 Ranges of concentration of eU, eTh and $\mathrm{K}$ in the rocks of the different types of lithology

\begin{tabular}{lllll}
\hline Type of lithology & $\mathrm{eU}(\mathrm{ppm})$ & $\mathrm{eTh}(\mathrm{ppm})$ & $\mathrm{K}(\%)$ & $\begin{array}{l}\text { Color in the eTh } \\
\text { map (Fig. 14) }\end{array}$ \\
\hline A & $0.5-4$ & $3-35$ & $0.2-2$ & Blue \\
B (B1,B2) & $5-12$ & $35-100$ & $2-5$ & Light pink \\
C & $5-12$ & $35-100$ & $1-2.5$ & Pink \\
D & $2.2-5$ & $10-35$ & $2-5$ & Yellow and green \\
\hline
\end{tabular}

outcrops of crystalline basement and the presence of the intrusive formation. The high radiometric anomalies are also present on the southeast corner and near center as well as some local points in the north. The local places with high concentrations of $\mathrm{K}$, eU and $\mathrm{eTh}$ may be connected with the intrusive suits (granite, pegmatite). The low concentrations of $\mathrm{K}(0.4-1.2 \%)$, eU (0.5-3.5 ppm) and eTh (3-20 ppm) are prevalent; such low radioactivity is more than $60 \%$ of the total area, suggesting the presence of the carbonate, silicate formation and quaternary sediments. For better recognition of the lithology, the relations between the concentrations of the radioactive elements measured on some selected profiles (as shown in Fig. 12) are presented in Fig. 13a-f.

Generally, the relationship between $\mathrm{U}$ and Th concentration is linear, suggesting that the $\mathrm{U}$ and Th are accompanying each other. The high concentrations of $\mathrm{U}$ and $\mathrm{Th}$ are characteristic of the widespread intrusive rocks (granite, syenite) in the studied region as well as in other parts of Nigeria (Adepelumi and Falade 2017). The high concentration of $\mathrm{Th}$ and $\mathrm{U}$ can be related also to the $\mathrm{Fe}$ or another metal element deposits formed by the magmatic activities.

The relations between $\mathrm{K}$, Th or $\mathrm{U}$ are more complicated in comparisons with that of $\mathrm{U}$ and $\mathrm{Th}$. Since $\mathrm{U}$ and Th belong to the actinide elements, they have similar geochemical properties, while $\mathrm{K}$ is the alkaline element, so its geochemical characteristics differ from that of $\mathrm{U}$ and $\mathrm{Th}$. Generally, potassium concentration ranges from a few tenth percent up to five percent, suggesting no potassium salt deposit. The high concentration of potassium together with high $\mathrm{U}$ and $\mathrm{Th}$ can indicate the places of the outcrop of the intrusive formation.

Based on the measured concentrations of eU, eTh and K, the rocks in the studied area can be divided into four types of lithology. The intervals of the variation of the $U$, Th and $\mathrm{K}$ for each lithology are summarized in Table 2.

The A type can be characteristic for the most of common rocks, such as metasedimentary rocks and some quaternary sediments. The B type is composed of the rocks or deposit with the highest concentrations of $\mathrm{U}$, Th and $\mathrm{K}$. The rocks could be the igneous, metavolcanic rocks or deposits rich in radioactive elements. The $\mathrm{C}$ type has a high concentration of $\mathrm{U}$ and $\mathrm{Th}$ and moderate concentration of $\mathrm{K}$ suggesting the occurrence of the fine-grained clastic, syenite or pegmatites.
Fig. 14 Lithological zones A-D designations (see Table 2) on the background of eTh concentration map (see Fig. 11b)

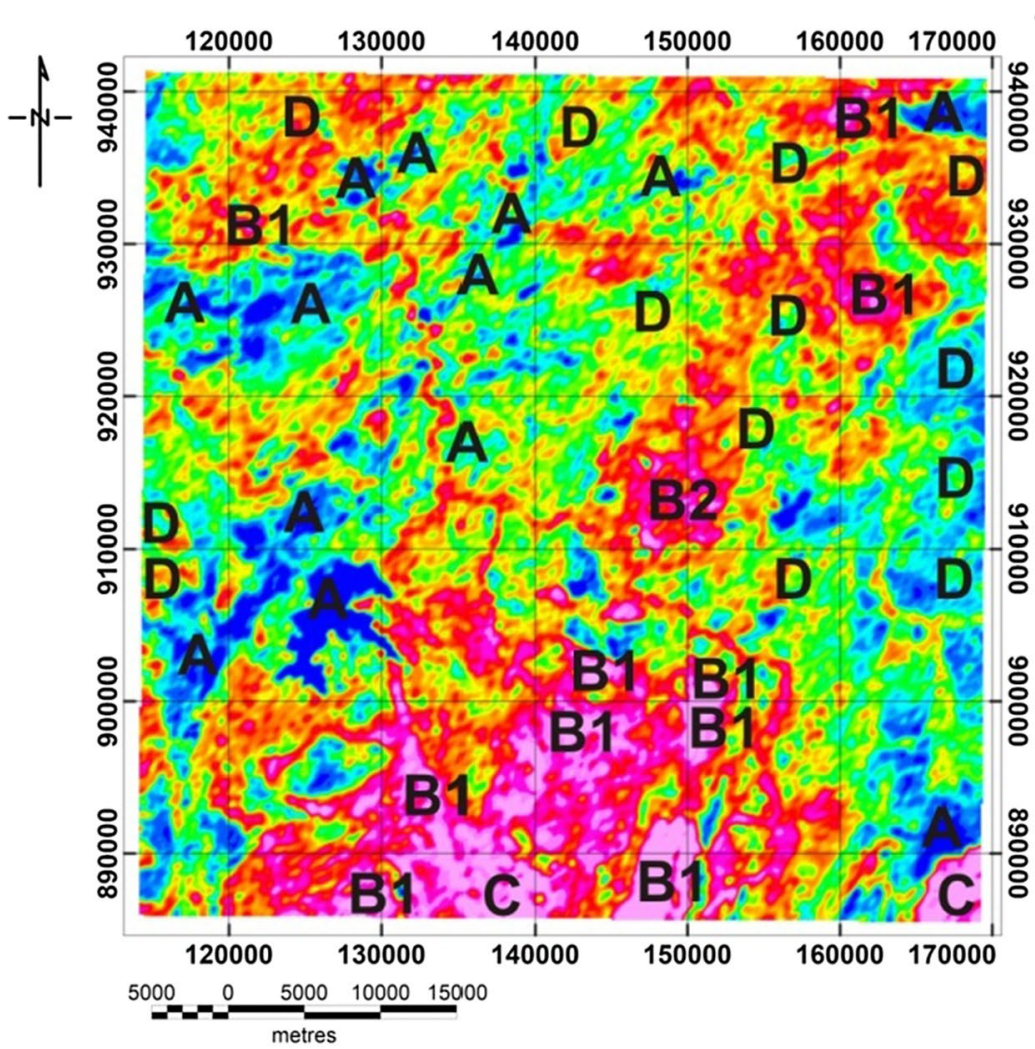

Th [ppm]

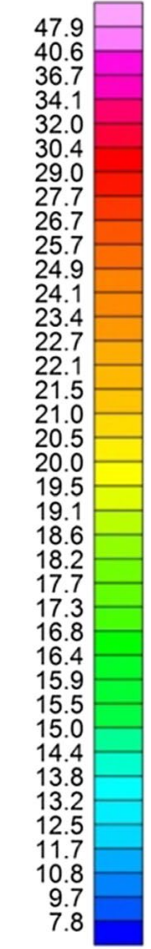


The $\mathrm{D}$ type is characterized by moderate $\mathrm{U}$ and Th concentration but relatively high concentration of potassium suggesting the occurrences of metamorphic rocks such as granite-gneiss, migmatite and schists (Dentith and Mudge 2014). The rocks of this type are present majorly in the southern part of the area and some places, where there are outcrops of crystalline basement. All the lithology types are shown in color on the eTh map (Fig. 14). Generally, the formations A, $\mathrm{B}, \mathrm{C}$ and $\mathrm{D}$ are trending in the SW-NE direction conscious with the area tectonics (compare Figs. 7a and 14).

The boundaries between the identified rock types presented in Fig. 14 generally are trending in the SE-NW. Figure $15 \mathrm{a}-\mathrm{c}$ illustrates the maps of $\mathrm{eTh} / \mathrm{eU}, \mathrm{eTh} / \mathrm{K}$ and $\mathrm{eU} / \mathrm{K}$, respectively.

(a)
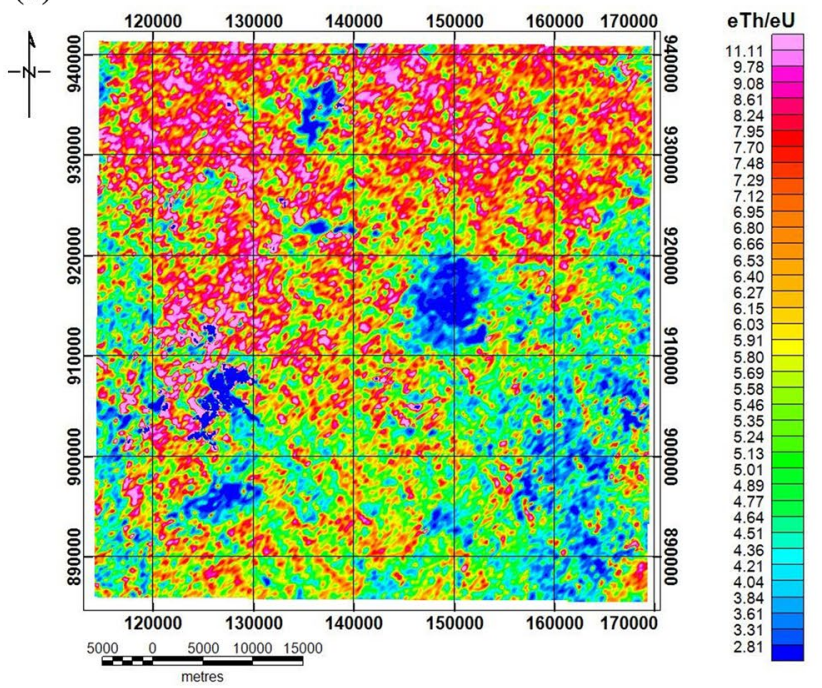

(c)

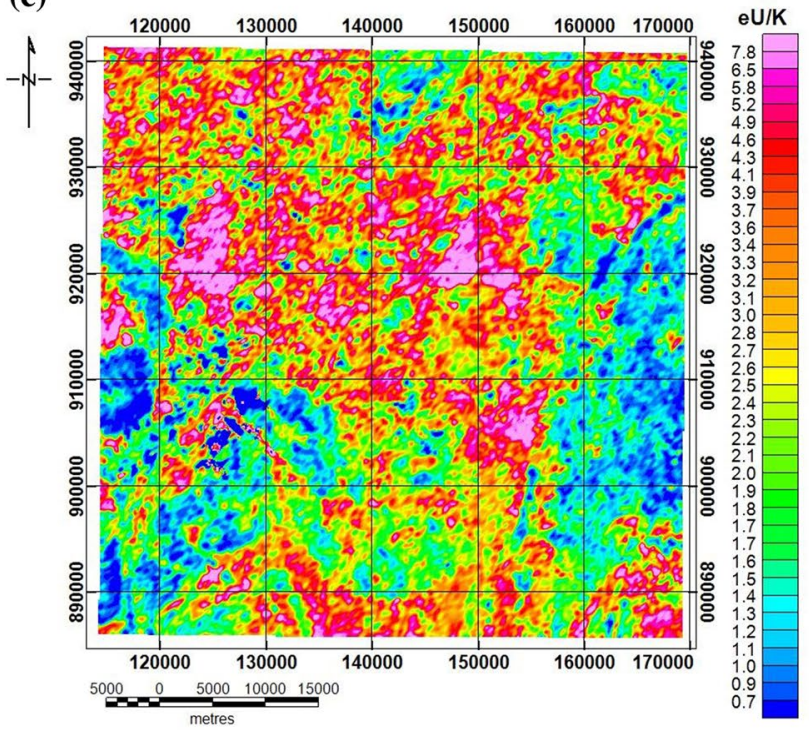

The average mass concentration of thorium, uranium and potassium in the Earth crust is $10 \mathrm{ppm}, 3.5 \mathrm{ppm}$ and $2.5 \%$, respectively, so the average ratio amounts to $\sim 3.5$ for $\mathrm{eTh} / \mathrm{eU}, \sim 4.0$ for $\mathrm{eTh} / \mathrm{K}$ and $\sim 1.4$ for eU/K. Reference to the mentioned ratio values, Fig. 15a-c indicates that the gamma radiation of the study region is mostly generated from the isotopes of thorium and uranium decay series. The zones are rich in $\mathrm{K}(\mathrm{eU} / \mathrm{K}<1.4$ and $\mathrm{eTh} / \mathrm{K}<3.5)$, contribute above $15 \%$ of the region area and mostly occur in SE and SW (Fig. 15b, c) and partly cover with the D zones (Fig. 14). According to Dickson and Scott (1977), Ohioma et al. (2017a, b) and Airo (2002), the K-rich zones could indicate the former hydrothermal alteration and can be potential gold deposits. The zones B in Fig. 14 have the similar concentrations of eTh, eU and $\mathrm{K}$, but the ratio of $\mathrm{eTh} / \mathrm{eU}$ at the

(b)
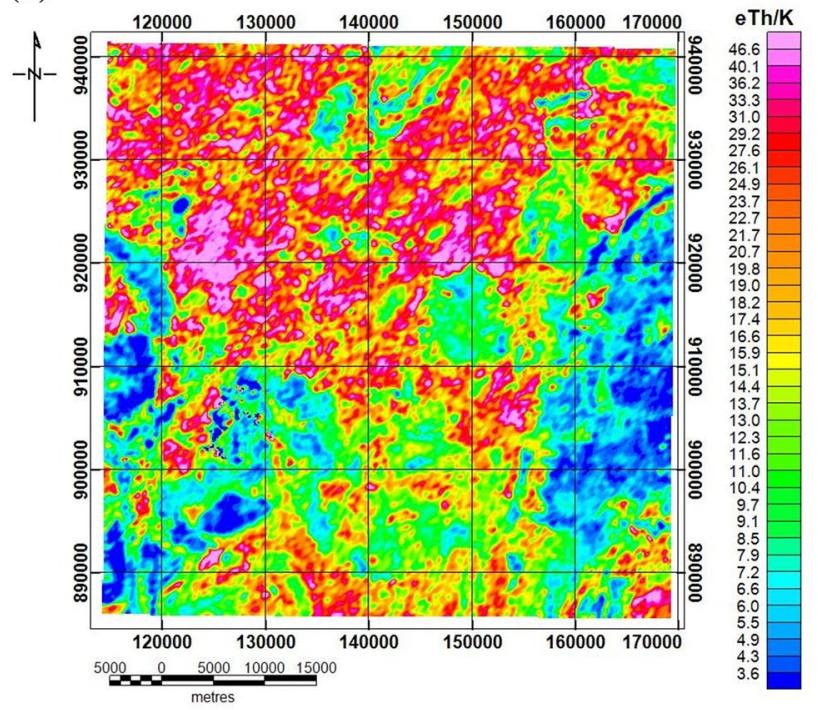

Fig. 15 Maps of radionuclides mass ratios a eTh/eU, b eTh/K and $\mathbf{c} \mathrm{eU} / \mathrm{K}$ 
Fig. 16 Map of U-eTh/3.5



center place signed as B2 is near 3.0 and significantly lower than that in the south places signed as B1 (eTh/eU: 5.0-7.0). The fact is probably related to reduction in $\mathrm{Th}$ in the zone B2 (eTh $36 \mathrm{ppm}, \mathrm{eU} \sim 9.5 \mathrm{ppm}, \mathrm{K} \sim 4.1 \%$ ) in comparison with the zones B1 (eTh 45 ppm, eU 9.5 ppm, $\mathrm{K} \sim 3 \%$ ) (Fig. 15a-c). The observation is confirmed by the map of U-Th/3.5 (Fig. 16). The B2 zone is more homogeneous and suggests that it is the magmatic rock without controlled by the geological processes; on the other hand, the B1 zones also are dominated by intrusive formations, but they were inhomogeneous and may be controlled by different geological processes; in consequence, the rocks of the B1 zones could be metamorphosed or fractured.

\section{Conclusions}

The aeromagnetic and aeroradiometric data obtained for the Isanlu sheet 225, North Central Nigeria, were interpreted with a view to delineate geological structures and the lithology. The aeromagnetic data delineate main structures trending principally in the SW-NE direction, which is in general consistent with that of structures of similar terrain (schist belts) in Nigeria. In the western part, there are zones with many deeper subsurface structures which are thought to be faults/fractures or possibly veins/dykes trending in the WNW-ESE direction. In the center of the study area, there is a long fault (occurring on $30 \mathrm{~km}$ (Figs. 3a, b, 4a, b, 9)site with arrow) crosscutting different subsurface lithologies.
The analytic signal map shows the zones occurrence of igneous, metasedimentary and migmatite rocks (Fig. 8b).

Aeroradiometric results in the SE corner of the Isanlu sheet 225 depict crystallized hardness formation with very high concentration of eTh and moderate eU but relatively low K. Generally, the concentration of eU is linearly proportional to that of eTh, suggesting the elements accompanying themselves in most rocks present in the studied area. The zones of eU with the concentration of 2-8 ppm and Th from 5 to 35 ppm contribute near $90 \%$ of the whole area. The zone with high concentration of eU (8-12 ppm) and eTh (36-95 ppm) dominates the south-center, SE corner and some local places distributed in the NE corner and a few points in the upper parts. These zones can be connected with the outcrop of basement, igneous or crystalline metamorphose suites or the relatively skarn districts connected with precious metals (Ohioma et al. 2017a,b). The zones of low eU, eTh and K covers above $60 \%$ of the area and mainly predominate in the north part, indicating the presence of the migmatite-gneiss-quartzite complex of the pelitic schists, phyllites and carbonate rocks and quaternary sediments on the surface. Based on the radiometric data, the rocks can be classified into four types A, B, C and D. The A type is composed of the rocks with relatively low concentrations of the natural radionuclides, the $\mathrm{B}$ type with the highest concentration of the natural radioactive elements, the $\mathrm{C}$ type with high concentration of both $\mathrm{eU}$ and $\mathrm{eTh}$ but relatively low potassium, and the type D with moderate eU and eTh but relatively high potassium. From 
the isotope ratio point of view, the zones $\mathrm{B}$ can be divided into $\mathrm{B} 1$ and $\mathrm{B} 2$. The rocks in the $\mathrm{B} 1$ zones probably are inhomogeneous and fractured, while the rocks in the B2 zone are homogeneous. The rocks in the $\mathrm{D}$ zones are most probably hydrothermal-altered suggesting gold potential elevated regions.

Acknowledgements Nigerian Geological Survey Agency is appreciated for making the data available. The results are part of the statutory research AGH University of Science and Technology, Krakow, Poland, Project No. 11.11.140.645. The paper was financially supported from the research subsidy nr. 16.16.140.315 at the Faculty of Geology, Geophysics and Environmental Protection of the AGH University of Science and Technology, Krakow, Poland, 2019. We would like to express our thanks to reviewers for their valuable remarks.

\section{Compliance with ethical standards}

Conflict of interest On behalf of all authors, the corresponding author states that there is no conflict of interest.

Open Access This article is licensed under a Creative Commons Attribution 4.0 International License, which permits use, sharing, adaptation, distribution and reproduction in any medium or format, as long as you give appropriate credit to the original author(s) and the source, provide a link to the Creative Commons licence, and indicate if changes were made. The images or other third party material in this article are included in the article's Creative Commons licence, unless indicated otherwise in a credit line to the material. If material is not included in the article's Creative Commons licence and your intended use is not permitted by statutory regulation or exceeds the permitted use, you will need to obtain permission directly from the copyright holder. To view a copy of this licence, visit http://creativecommons.org/licenses/by/4.0/.

\section{References}

Adelana SMA, Olasehinde PI, Bale RB, Vrbka P, Edet AE, Goni IB (2008) An overview of the geology and hydrogeology of Nigeria. Appl Groundw Stud Afr 13:171-197

Adepelumi AA, Falade AH (2017) Combined high-resolution aeromagnetic and radiometric mapping of uranium mineralization and tectonic settings in Northeastern Nigeria. Acta Geophys 65:1043-1068

Airo ML (2002) Aeromagnetic and aeroradiometric response to hydrothermal alteration. https://www.researchgate.net/publi cation/226294877

Airo ML, Loukola-Ruskeeniemi K (2004) Characterization of sulfide deposits by airborne magnetic and gamma-ray responses in eastern Finland. Ore Geol Rev 24:67-84

Armstrong M, Rodeghiero A (2006) Airborne geophysical techniques in Aziz. In: Materials of coal operators' conference. University of Wollongong and Australian Institute of Mining and Metallurgy, pp 113-131

Boadi B, Wemegah DD, Preko K (2013) Geological and structural interpretation of the Konongo area of the Ashanti gold belt of
Ghana from aeromagnetic and radiometric data. Int Res J Geol Min 3(3):124-135

Burke K, Dewey JF (1972) Orogeny in Africa. In: Dessauvagie TFJ, Whiteman AJ (eds) African geology. Ibadan University Press, Ibadan, pp 583-608

Dentith M, Mudge ST (2014) Geophysics for the mineral exploration geoscientist. Cambridge Univesity Press, Cambridge. ISBN 978-0-521-80951-1

Dickson BL, Scott KM (1977) Interpretation of aerial gamma-ray survey - adding the geochemical factors. AGSO J Australian Geol Geophys 17(2):187-200

Everett ME (2013) Near-Surface Applied Geophysics. Cambridge University Press, New York. https://doi.org/10.1017/CBO9781139 088435

Fitches WR, Ajibade AC, Egbuniwe IG, Holt RW, Wright JB (1985) Late Proterozoic schist belts and plutonism in NW Nigeria. J Geol Soc 142(2):319-337

Foote RS, Humphrey NB (1976) Airborne radiometric techniques and application to uranium exploration. Exploration for uranium ore (IAEA-SM 208/47). IAEA, Vienna.

Foss C (2011) Magnetic data enhancements and depth estimation. In: Encyclopedia of solid earth geophysics, pp 736-746

Leu LK (1982) Use of reduction-to-the-equator process for magnetic data interpretation. Geophysics 47(4):445-445

Milligan PR, Gunn PJ (1997) Enhancement and presentation of airborne geophysical data. J Aust Geol Geophys 17(2):63-75

Nigerian Geological Survey Agency (2006) Geological map of Nigeria 1:1000 000

Nigerian Geological Survey Agency NGSA (2010) Airborne geophysical digital data dissemination guidelines

Obaje NG (2009) Geology and mineral resources of Nigeria. In: Lecture notes in earth sciences, vol 120. Springer, Berlin. ISBN 978-3-540-92685-6

Ohioma JO, Ezomo FO, Akinsunmade A (2017a) Delineation of hydrothermally altered zones that favour gold mineralization in Isanlu area, Nigeria using aeroradiometric data. Int Ann Sci 2(1):20-27

Ohioma JO, Adegbite JT, Ehilenboadiaye JI (2017b) Geophysical identification of hydrothermally altered structures that favour gold mineralization. J Appl Sci Environ Manag 21(6):1047-1050

Oluyide PO, Nwajide CS, Oni AO (1998) The geology of the Ilorin with exploration on the 1:250,000 series, sheet 50 (Ilorin). Geol Surv Niger Bull 42:1-84

Oyawoye MO (1972) The basement complex of Nigeria. In: Dessauvagie TFJ, Whiteman AJ (eds) African geology. University of Ibadan Press, Ibadan, pp 67-99

Parasnis DS (1986) Principles of applied geophysics. Chapman and Hall, Boca Raton, pp 3-60

Petecki Z, Rosowiecka O (2017) A new magnetic anomaly map of Poland and its contribution to the recognition of crystalline basement rocks. Geol Q. https://doi.org/10.7306/gq.1383

Telford WM, Telford WM, Geldart LP, Sheriff RE, Sheriff RE (1990) Applied geophysics. Cambridge University Press, Cambridge

Thébault E, Finlay CC, Alken P, Beggan CD, Canet E, Chulliat A, Langlai B, Lesur V, Lowes F, Manoj C (2015) Evaluation of candidate geomagnetic field models for IGRF-12. Planets Space 67:112. https://doi.org/10.1186/s40623-015-0273-4

Woakes M, Rahaman MA, Ajibade AC (1987) Some metallogenetic features of the Nigerian basement. J Afr Earth Sci 6(5):655-664

www.gpxsurveys.com.au 